Malgorzata MarkowsKa

Uniwersytet Ekonomiczny we Wrocławiu, Polska

ANDRZEJ SoKoŁOWsKI

Uniwersytet Ekonomiczny w Krakowie, Polska

DANUTA STRAhL

Uniwersytet Ekonomiczny we Wrocławiu, Polska

\title{
Taksonomia dynamiki zmian struktury zatrudnienia w nowoczesnym przemyśle i usługach w regionach Unii Europejskiej ${ }^{1}$
}

\author{
The taxonomy of employment structure changes \\ in modern industry and services \\ in the European Union regions
}

Streszczenie: Celem pracy jest analiza zmian udziału zatrudnionych w nowoczesnych, rozwiniętych technologicznie usługach i przemyśle w regionach Unii Europejskiej na poziomie NUTS 2. Wykorzystano dane z lat 1999-2008, kiedy były one w miarę kompletne i porównywalne. Dla każdej cechy osobno i dla każdego regionu oszacowano tendencję rozwojową. Współczynniki trendu potraktowano jako zmienne wejściowe do analizy taksonomicznej. Przy pomocy metody Warda zidentyfikowano liczbę grup regionów, różniących się modelem dynamiki zmian zatrudnienia w analizowanych sferach. Ostateczny podział regionów ze względu na dynamikę uzyskano przy pomocy metody k-średnich. Wyniki grupowania były weryfikowane przy pomocy jednoczynnikowej analizy wariancji. Na końcu ustalono modele dynamiki typowe dla wyróżnionych grup regionów.

Abstract: The objective of the study is to analyze changes of employment share in modern, high-tech services and industry in the European Union regions at NUTS 2 level. The data covering the period of 1999-2008 were used since they are relatively complete and comparable. The growth tendency, separately for each quality/property and for each region, was estimated. Trend coefficients were used as input variables for the purposes of cluster analysis. By applying Ward's method identified was the number of regional clusters, which differ by the model of employment changes dynamics in the analyzed spheres. The ultimate division of regions in terms of dynamics was obtained by using the k-means

${ }^{1}$ Projekt został sfinansowany ze środków Narodowego Centrum Nauki przyznanych na podstawie decyzji numer DEC-2013/09/B/HS4/00509. 
method. The results of clustering were verified by applying one-way analysis of variance. Finally the models of dynamics typical for the distinguished clusters of regions were specified.

Słowa kluczowe: analiza trendu; NUTS 2; taksonomia dynamiczna

Keywords: dynamic clustering; NUTS 2; trend analysis

\section{W STĘP}

Nowoczesny przemysł i usługi na obecnym etapie rozwoju cywilizacyjnego odgrywają istotną rolę w gospodarce. Nowoczesny przemysł to nie tylko nowe, dynamicznie rozwijające się branże przemysłu „wysokiej techniki”, ale również branże tradycyjne, poddawane permanentnej modernizacji. Wdrażanie automatyzacji i robotyzacji w procesach technologicznych pozwala na wytwarzanie nowoczesnych i wysoko konkurencyjnych produktów. Natomiast informacyjna faza rozwoju sprzyja wprowadzaniu nowych rodzajów usług, które związane są m.in. z pracą na nowych urządzeniach, obsługą biznesową, logistyką, magazynowaniem (Zioło, 2010, 2012).

Celem pracy jest analiza dynamiki zmian struktury zatrudnienia w nowoczesnym przemyśle i usługach w regionach Unii Europejskiej na poziomie NUTS 2 w latach 1999-2008. Poszukuje się grup regionów charakteryzujących się podobną dynamiką wybranych wskaźników zatrudnienia poprzez oszacowanie trendów liniowych, a następnie potraktowanie ocen parametrów tych trendów jako charakterystyk wykorzystywanych w metodach taksonomicznych. To prowadzi do zidentyfikowania różnych modeli zmian struktury zatrudnienia w badanych działach.

\section{PRZEGLĄD WYBRANYCH BADAŃ}

Pojęcia „struktura” i „zmiany strukturalne” są wszechobecne w analizach ekonomicznych (chociaż ich interpretacja i znaczenie mogą być odmienne). Struktura gospodarki nie jest bowiem dana na stałe i w trakcie procesów wzrostu/hamowania gospodarczego ulega zmianom. Do głównych powodów zmian zalicza się: zmiany w strukturze popytu, różnice w tempie wzrostu wydajności pracy w gałęziach gospodarki, zmiany relatywne cen, rozwój światowego handlu (procesy globalizacji) i politykę liberalizacji gospodarki.

W ekonomii zmiany strukturalne oceniane są głównie poprzez badanie zmian struktury produkcji oraz struktury wykorzystania czynników produkcji. Analizowane są zwykle względne zmiany znaczenia różnych sektorów w czasie, mierzone przez udział poszczególnych gałęzi w tworzeniu PKB, albo zmiany struktury zatrudnienia. W ekonomii rozwoju i historii gospodarczej zmiana strukturalna rozumiana jest zaś jako „nowy rozkład aktywności produkcyjnej w gospodarce oraz nowy rozkład czynników produkcji na różne sektory gospodarki, różne zawody, regiony geograficzne, rodzaje produktów itd.” (Machlup, 1991: 76 za Memedovic, Iapadre, 2010: 1). 
Pomimo że koncepcja zmian strukturalnych definiowana jest w różny sposób, najczęściej odnoszona jest do długoterminowych i trwałych zmian w strukturze sektorowej systemów gospodarczych (Chenery i in., 1986; Syrquin, 2007).

Ważny aspekt związany z przeobrażeniami gospodarki stanowią zmiany lokalizacji działalności gospodarczej, procesy urbanizacji oraz, w szerszym sensie, zmiany w otoczeniu instytucjonalnym.

Zmiany zachodzące w gospodarce stanowią inspirujące pole badawcze i stwarzają nowe możliwości rozpoznania reguł ich kształtowania w coraz bardziej różnicujących się układach przestrzennych.

Przykładowo przedmiotem raportu, który przygotowali O. Memedovic i L. Iapadre (2010), była analiza trendów w sektorach w gospodarce światowej w latach 1970-2008. Autorzy dokonali także przeglądu literatury i badań prowadzonych w tym zakresie, wskazując m.in., iż tematyka ta cieszyła się zainteresowaniem ekonomistów od dawna. Już w wieku XVIII w pracach, które przedstawili: F. Quesnay (1758), A.R.J. Turgot (1766) i J. Steuart (1767) obecne były zagadnienia zmian strukturalnych. Również A. Smith (1776)j79

wskazywał na silne związki cech strukturalnych z poziomem rozwoju gospodarczego. Natomiast D. Ricardo (1817) uważał właśnie zmiany składowych systemu produkcyjnego za podstawy gospodarczego rozwoju.

Główne wnioski z badań 40-letnich trendów w gospodarce światowej są następujące (Memedovic, Iapadre, 2010):

1. Spowolnieniu uległ w ostatniej dekadzie długookresowy wzrost udziału usług w globalnej wartości dodanej.

2. Rosnący udział krajów Ameryki Północnej i Azji w globalnej wartości dodanej uległ częściowo odwróceniu na korzyść innych regionów.

3. Po pewnym zahamowaniu w latach 80 . XX w. zaobserwowano w ostatnich dwóch dekadach przyspieszenie w przekształceniach strukturalnych w sektorze produkcyjnym.

W nurt badań nad zmianami strukturalnymi w gospodarce wpisuje się opracowanie opisujące zachodzące w Europie procesy serwicyzacji (wzrostu znaczenia sektora usług), które przygotował G. Lux (2010). Zmiany strukturalne światowego przemysłu w społeczeństwie postindustrialnym i przesunięcia strukturalne w światowej alokacji produkcji wysoce zaawansowanej technologicznie badały I. Rodionova i T. Kokuytseva (2010). Na znaczenie nowoczesnego przemysłu dla rozwoju terytorium, w tym aglomeracji, wskazuje A. Klasik (2011).

Z. Zioło (2012) podkreśla, że konieczne są także badania pozwalające na ocenę efektywności układów przestrzennych, co umożliwi określenie dalszych kierunków przemian. Analizy dynamiczne dają podstawy dla scenariuszy rozwojowych, co sprzyja tworzeniu propozycji działań na rzecz racjonalnego kształtowania procesów przemian gospodarczych. Ciągłe zmiany implikują poszukiwanie takich metod analizy, które pozwolą na określanie funkcji przemysłu i usług w kształtowaniu gospodarki opartej na wiedzy. 


\section{Proponowana METODA BADAWCZA}

Zastosowana metoda przewiduje oszacowanie trendów liniowych dla każdej z analizowanych cech i osobno dla każdego regionu. Badany okres obejmuje 10 lat, więc nawet przy ewentualnych zmianach nieliniowych aproksymacja trendem liniowym wskazuje ogólną tendencję zjawisk. Oszacowane trendy dają nowe cechy statystyczne charakteryzujące regiony, a właściwie dynamikę wybranych wskaźników zatrudnienia. Owe nowe cechy to wyrazy wolne oraz współczynniki kierunkowe czterech trendów. Mamy więc poziom (punkt wyjścia) scharakteryzowany przez wyraz wolny oraz dynamikę - poprzez współczynnik kierunkowy. Osiem nowych cech, o których mowa, zostało poddanych klasycznej standaryzacji poprzez odjęcie średniej i podzielenie przez odchylenie standardowe. Zmienne standaryzowane wykorzystano w taksonomicznej metodzie Warda (Ward, 1963) (ryc. 1).

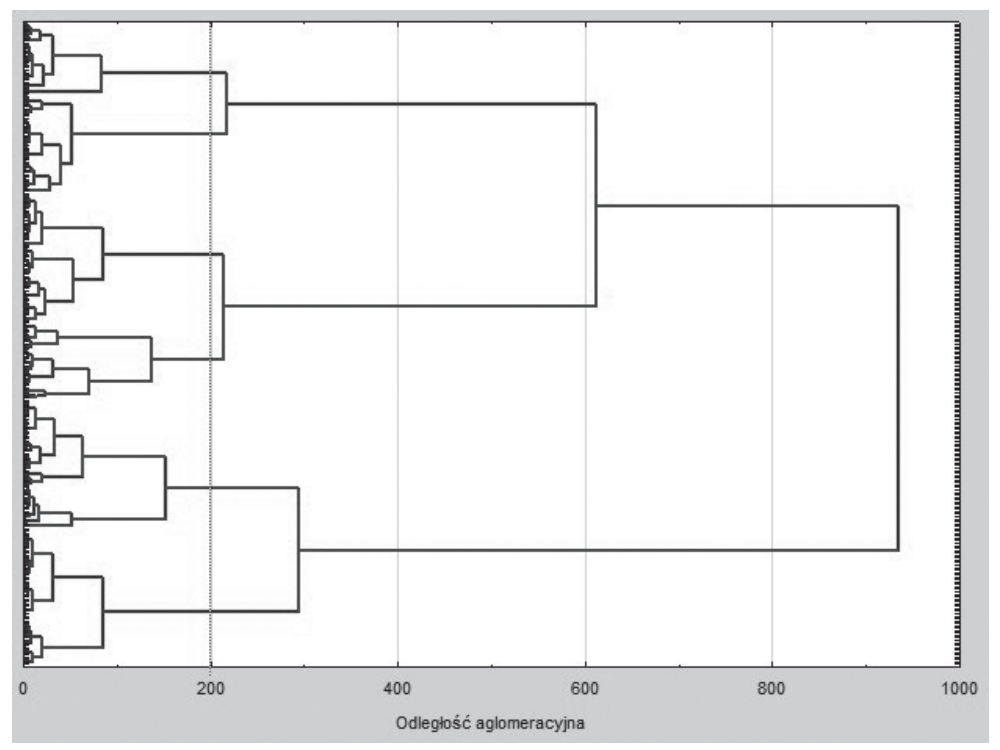

Ryc. 1. Dendrogram uzyskany metodą Warda dla regionów Unii Europejskiej ze względu na oceny parametrów trendów udziałów pracujących w usługach opartych na wiedzy oraz w wysoko i średnio zaawansowanym przemyśle

Źródło: opracowanie własne

Analiza dendrogramu pozwala na ustalenie liczby grup lub, mówiąc inaczej, charakterystycznych wzorców dynamiki wskaźników zatrudnienia. Ostateczny podział regionów dokonywany jest przy pomocy metody k-średnich. Obliczenie średnich parametrów trendów w grupach pozwala na zidentyfikowanie, zróżnicowanie i opis wzorców. Można też wskazać region najbardziej typowy dla danej grupy, leżący najbliżej jej środka. Podkreślamy, że uzyskane wzorce mają charakter wielowymiarowy, gdyż w zastosowanych tu metodach taksonomicznych uwzględnianych jest jednocześnie osiem parametrów czterech trendów. 


\section{CECHY STATYSTYCZNE - KRÓTKA CHARAKTERYSTYKA}

Na potrzeby analizy zmian $w$ strukturze zatrudnienia w nowoczesnym przemyśle i usługach wybrano w celu dokonania oceny unijnych regionów szczebla NUTS 2 następujące cechy na podstawie dostępności danych w statystycznych bazach Eurostatu:

- KIS - pracujący w usługach opartych na wiedzy (knowledge-intensive services) jako procent siły roboczej;

- KIS 2 - pracujący w usługach opartych na wiedzy jako procentowy udział pracujących w usługach;

- HIT - pracujący w przemyśle wysoko i średnio zawansowanym technologicznie (jako $\%$ siły roboczej);

- HIT 2 - procentowy udział pracujących w przemyśle wysoko i średnio zawansowanym technologicznie w ogólnej liczbie pracujących w przemyśle.

Zakres czasowy analizy informacji statystycznych obejmuje lata 1999-2008. Jest to okres, w którym można uchwycić symptomy kryzysu i jednocześnie czas, dla którego sposób zbierania danych umożliwia ich porównywalność.

W roku 2008 w Unii Europejskiej na szczeblu NUTS 2 funkcjonowało 271 regionów (Regions, 2007), przy czym ze względu na braki w danych nie uwzględniono w analizie następujących regionów: francuskich zamorskich (Guadeloupe, Martinique, Guyane, Réunion) oraz hiszpańskich (Ciudad Autónoma de Ceuta i Ciudad Autónoma de Melilla). Oznacza to, że badanie dotyczyło 97,8\% wszystkich regionów NUTS 2 .

Ze wstępnej analizy danych dotyczących struktury zatrudnienia w nowoczesnym przemyśle i usługach wynika, iż w roku 2008 w relacji do roku 1999 obniżenie wartości odnotowano:

- ze względu na wartości cechy HIT dla 163 regionów UE szczebla NUTS 2;

- dla wartości HIT 2 w przypadku 131 regionów;

- ze względu na udział pracujących w usługach opartych na wiedzy w ogólnej liczbie pracujących w usługach $\mathrm{w}$ regionie w 59 regionach;

- pod względem udziału pracujących w usługach opartych na wiedzy w ogólnej liczbie pracujących w regionie w 23 regionach.

Największe zaś wzrosty w badanym okresie odnotowano w przypadku HIT - o 275\% w rumuńskim regionie Vest, a o $143 \%$ dla HIT 2 na Łotwie. Dla KIS był to przyrost o $67 \%$ w rumuńskim regionie Sud-Muntenia, natomiast dla KIS 2 o 34,3\% we włoskim regionie Provincia Autonoma Trento.

Rozstęp ustalony dla analizowanych cech jako stosunek wartości maksymalnej do minimalnej wskazuje na ich odmienne zróżnicowanie, ze względu na wartości skrajne (tab. 1). Dla udziału pracujących w usługach opartych na wiedzy w ogólnej liczbie pracujących relacja ta uległa zmniejszeniu z 7,9 (wartość maksymalna dla Inner London, a minimalna dla rumuńskiego Sud-Muntenia) w roku 1999, do 5,4 (Inner London - wartość maksymalna, a minimalna w rumuńskim regionie Sud-Vest Oltenia) w roku 2008. Dla kolejnej cechy - KIS 2 - rozstęp zmniejszył się z 3,5 do 2,9 (wartości maksymalne w obu latach w fińskim Åland, a minimalne w greckich regionach Ionia Nisia w roku 1999, zaś Notio Aigaio w 2008 roku). 
Taksonomia dynamiki zmian struktury zatrudnienia w nowoczesnym przemyśle... 51

Tab. 1. Podstawowe charakterystyki analizowanych cech

\begin{tabular}{|l|r|r|r|r|r|r|r|r|}
\hline \multirow{2}{*}{ Wyszczególnienie } & \multicolumn{2}{|c|}{ KIS } & \multicolumn{2}{c|}{ KIS 2 } & \multicolumn{2}{c|}{ HIT } & \multicolumn{2}{c|}{ HIT 2 } \\
\cline { 2 - 10 } & 1999 & 2008 & 1999 & 2008 & 1999 & 2008 & 1999 & 2008 \\
\hline max & 58,2 & 60,6 & 76,4 & 73,5 & 20,5 & 21,4 & 55,9 & 59,0 \\
\hline min & 7,8 & 11,2 & 21,8 & 25,2 & 0,6 & 0,6 & 1,95 & 3,9 \\
\hline średnia & 28,9 & 32,4 & 45,4 & 48,0 & 6,8 & 6,4 & 23,2 & 22,9 \\
\hline mediana & 28,5 & 32,1 & 45,0 & 48,1 & 6,6 & 5,6 & 22,7 & 22,5 \\
\hline odchylenie standardowe & 8,9 & 8,9 & 8,3 & 7,6 & 3,6 & 3,7 & 10,2 & 10,0 \\
\hline współczynnik zmienności & 30,8 & 27,4 & 18,2 & 15,9 & 52,5 & 57,9 & 43,8 & 43,5 \\
\hline max/min & 7,9 & 5,4 & 3,5 & 2,9 & 37,3 & 34,0 & 28,7 & 15,2 \\
\hline max - min & 50,9 & 49,3 & 54,6 & 48,3 & 20,0 & 20,8 & 54,0 & 55,1 \\
\hline
\end{tabular}

Źródło: opracowanie własne na podstawie danych Eurostatu

Zdecydowanie większe wartości rozstępu obserwowano dla cechy HIT, bowiem w pierwszym okresie relacja maksimum (Stuttgart) do minimum (grecki region Voreio Aigaio) wynosiła 37,3. Natomiast w roku 2008 stosunek ten był na poziomie 34 (dla niemieckiego regionu Braunschweig i greckiego Voreiro Aigaio). Ponadto dla cechy HIT 2 rozpiętość ta uległa zmniejszeniu: z 26,7 (wartość maksymalna we włoskim Valle d'Aosta, minimalna w greckim Voreio Aigaio), do 15,2 (dla niemieckiego regionu Braunschweig oraz uplasowanego na ostatnim miejscu pod względem wartości HIT 2 w 2008 roku Cypru).

Na tym samym poziomie pozostała wartość minimum dla HIT, dla pozostałych cech odnotowano wzrost tej statystyki. Również wartość maksimum wzrosła dla trzech cech, zaś obniżenie wartości w roku 2008 odnotowano jedynie dla KIS 2. Spadek wartości średniej i mediany w analizowanym okresie jest charakterystyczny dla HIT i HIT 2.

\section{SYTUACJA ZATRUDNIENIA W NOWOCZESNYM PRZEMYŚLE}

\section{USŁUGACH W REGIONACH EUROPEJSKICH}

Rozmieszczenie regionów pod względem udziału pracujących w sektorze usług opartych na wiedzy w ogólnej liczbie pracujących w regionie, szczególnie w grupach skupiających regiony o najwyższych i najniższych poziomach KIS w obu analizowanych okresach, niewiele się zmieniło. Charakterystyczne jest zdecydowane odstawanie regionów rumuńskich (z wyłączeniem regionu stołecznego), które cechują niskie wartości KIS. Znamienny jest także „efekt stolicy” szczególnie we Francji, Polsce, Hiszpanii, Portugalii, Grecji, Bułgarii czy we Włoszech albo na Słowenii. W grupach o wyższych wartościach KIS przeważają regiony krajów, które decydowały o początkach tworzenia UE, czyli państw założycielskich (EWG) oraz pierwszego rozszerzenia z roku 1973 (Dania, Wielka Brytania i Irlandia) i czwartego z 1995 roku (Szwecja, Finlandia i Austria).

Rozmieszczenie regionów (liczbę w klasie) uszeregowanych pod względem wartości analizowanych cech w roku 1999 i 2008 przedstawiono w tabeli 2. Dla skrajnych lat przedstawiono zakresy 10 utworzonych przedziałów (kolumna 1) oraz liczbę regionów, dla których wartości cechy znajdowały się w tym zakresie liczbowym (kolumna 2). 
Wyspecjalizowane usługi - oceniane przez pryzmat wysokiego udziału pracujących w sektorze usług opartych na wiedzy w ogólnej liczbie pracujących w usługach w regionie - obserwowane są zwłaszcza w kilku regionach skandynawskich, brytyjskich, duńskich i krajów Beneluksu.

W grupie regionów o oscylujących na poziomie 60\% i wyższych wartościach KIS 2 było 11 regionów w 1999 roku, a w roku 2008 liczba ta wzrosła do 19. Charakterystyczne jest obniżenie się górnego progu w najwyższym z utworzonych przedziałów. Może to mieć związek ze stale wzrastającym znaczeniem sektora usług w gospodarce, co może implikować mniejsze tempo ich wysokiej specjalizacji albo być oznaką „hamowania” gospodarki.

Efekt stolicy charakterystyczny jest dla KIS 2 m.in. we Francji, Portugalii, Rumunii, Czechach czy Austrii. W Wielkiej Brytanii oddziaływanie stolicy przejawia się wysokim udziałem pracujących w wyspecjalizowanych, opartych na wiedzy usługach w okalających stolicę regionach: Bedfordshire, Hertfordshire, Berkshire, Bucks and Oxfordshire, Essex, Surrey, East and West Sussex oraz Kent.

Względnie stabilny zakres wartości skrajnych cechuje regiony ze względu na udział pracujących w przemyśle wysoko i średnio zawansowanym technologicznie (jako procent siły roboczej), przy czym obserwowany jest ,nabór” regionów w grupach o najniższych wartościach HIT. W grupach regionów o wartościach HIT z trzech ostatnich przedziałów znalazło się odpowiednio 129 i 174 regiony, co stanowiło 49\% ogółu analizowanych regionów w 1999 roku oraz ponad 65\% w roku 2008 - wskazuje to na malejące znaczenie dla rynku pracy przemysłu wysoko i średnio zaawansowanego.

Warto podkreślić, iż regiony zaliczone do grup o niskich wartościach HIT rozproszone są niemal równomiernie po całym terytorium zjednoczonej Europy, natomiast do trzech pierwszych grup regionów pod względem wysokiego HIT należały w roku:

- 1999 - regiony niemieckie (Stuttgart, Karlsruhe, Freiburg, Tübingen, Schwaben, Oberbayern, Niederbayern, Oberpfalz, Mittelfranken, Unterfranken, Darmstadt, Braunschweig, Rheinhessen-Pfalz), regiony francuskie (Alsace i Franche-Comté) oraz pojedyncze regiony Włoch (Piemonte), Hiszpanii (Comunidad Foral de Navarra), Węgier (Közép-Dunántúl) i Wielkiej Brytanii (West Midlands),

- 2008 - niemal te same regiony w Niemczech (11) oraz wegierskie (Közép-Dunántúl, Nyugat-Dunántúl), czeskie (Strední Cechy, Jihozápad i Severovýchod), rumuński (Vest), słoweński (Západné Slovensko) i francuski (Franche-Comté).

Wysoki udział pracujących w przemyśle wysoko i średnio zawansowanym technologicznie w ogólnej liczbie pracujących w przemyśle (powyżej 39\%) w roku 1999 cechował 16 regionów. Były to terytoria północnych Niemiec (7 regionów) oraz regiony z Wielkiej Brytanii (4), dwa szwedzkie (Stockholm i Västsverige), holenderski (Zeeland), francuski (Franche-Comté) i włoski (Valle d'Aosta). Również w 2008 roku wysokie wartości HIT 2 dominowały $\mathrm{w}$ regionach północnych Niemiec oraz w pojedynczych regionach Węgier i Francji. W przypadku zaś południowych regionów Hiszpanii i Grecji w każdym z badanych momentów notowano najniższe wartości HIT 2.

Badając regiony pod kątem ich pozycji w uporządkowaniu pod względem udziału pracujących w usługach opartych na wiedzy w ogólnej liczbie pracujących w regionie (KIS), 


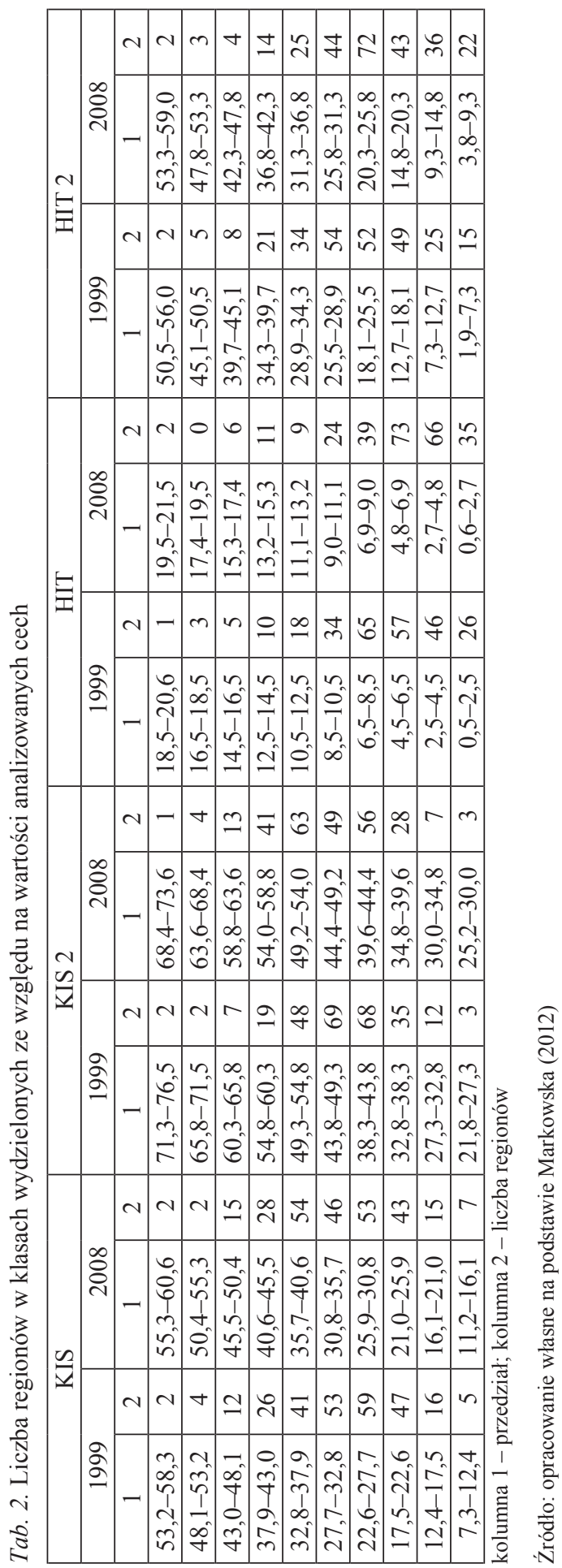


należy wskazać, iż zarówno w pierwszej, jak i w ostatniej dziesiątce znalazło się wiele tych samych regionów. I tak na początku uporządkowania było ich osiem: Inner London, Stockholm, Hovedstaden, Åland, Utrecht, Outer London, Surrey, East and West Sussex, Övre Norrland - a na końcu listy: Ionia Nisia, Sterea Ellada, Nord-Vest, Vest, Centru, SudEst, Sud-Muntenia, Nord-Est, Sud-Vest Oltenia, czyli dziewięć tych samych regionów.

Podobną sytuację - powtarzający się liderzy i „,maruderzy” uporządkowania - odnotowano także w przypadku pozostałych cech:

- KIS 2 - dziewięć tych samych regionów w pierwszej dziesiątce (Åland, Stockholm, Östra Mellansverige, Småland med öarna, Sydsverige, Norra Mellansverige, Mellersta Norrland, Övre Norrland, Inner London), a pięć na końcu uporządkowania (Canarias, Ionia Nisia, Sterea Ellada, Notio Aigaio, Algarve);

- HIT - po sześć powtarzających się regionów w pierwszej (Stuttgart, Braunschweig, Tübingen, Rheinhessen-Pfalz, Karlsruhe) i ostatniej (Extremadura, Canarias, Dytiki Ellada, Notio Aigaio Kriti Voreio Aigaio) dziesiątce uporządkowania;

- po pięć regionów powtarza się w pierwszej (Stuttgart, Braunschweig, RheinhessenPfalz, Karlsruhe i Oberbayern) i ostatniej (Extremadura, Canarias, Ipeiros, Notio Aigaio Kriti, Voreio Aigaio) dziesiątce uporządkowania pod względem udziału pracujących w przemyśle wysoko i średnio zaawansowanym technologicznie w ogólnej liczbie pracujących w przemyśle regionie (HIT 2) w roku 1999 i 2008.

\section{WYNIKI GRUPOWANIA REGIONÓW ZE WZGLĘDU NA POZIOM I DYNAMIKĘ ZATRUDNIENIA W NOWOCZESNYCH SEKTORACH}

Z danych zestawionych w tabeli 3 wynika, że w otrzymanych klasach najliczniejszą stanowi trzecia (52 regiony), następnie druga i pierwsza (odpowiednio 47 i 45 regionów). Najmniej liczne skupienie stanowi klasa czwarta (37 regionów).

Tab. 3. Średnie wartości wyrazów wolnych (a) i współczynników kierunkowych (b) trendów w grupach oraz średnie wartości wskaźnika innowacyjności

\begin{tabular}{|l|r|r|r|r|r|r|r|r|c|}
\hline \multirow{2}{*}{$\begin{array}{c}\text { Klasa } \\
\text { (liczebność) }\end{array}$} & \multicolumn{10}{|c|}{ SIT a } & HIT b & HIT2 a & HIT2 b & KIS a & KIS b & KIS2 a & KIS2 b & W w 2008 \\
\hline $1(45)$ & 5,822 & $-0,094$ & 24,727 & $-0,174$ & 40,692 & 0,204 & 56,062 & 0,035 & 46 \\
\hline $2(47)$ & 10,775 & $-0,342$ & 35,718 & $-0,763$ & 33,843 & 0,431 & 50,408 & 0,252 & 44 \\
\hline $3(52)$ & 8,173 & $-0,130$ & 26,913 & $-0,100$ & 27,910 & 0,723 & 43,278 & 0,734 & 39 \\
\hline $4(37)$ & 8,761 & 0,221 & 23,974 & 0,716 & 24,657 & 0,296 & 42,988 & 0,307 & 36 \\
\hline $5(40)$ & 4,234 & 0,019 & 14,995 & 0,033 & 23,368 & 0,153 & 42,507 & $-0,098$ & 26 \\
\hline $6(44)$ & 3,028 & 0,025 & 10,735 & 0,143 & 19,597 & 0,592 & 34,683 & 0,604 & 24 \\
\hline
\end{tabular}

Źródło: opracowanie własne 
Klasy zostały uporządkowane ze względu na wartość współczynnika W (indywidualne wartości wskaźnika innowacyjności), którego średnie, zamieszczone w tabeli 3, zostały zaczerpnięte z pracy Markowskiej (2012). Liczony był z wykorzystaniem ośmiu zmiennych charakteryzujących innowacyjność według typowej metodologii (np. Handbook, 2008) konstruowania wskaźników agregatowych, obejmującej normalizację wartości do przedziału [0;1], a następnie uśrednianie tych wartości z zadanym współczynnikiem skali (u nas 100):

a - średni wyraz wolny trendu regionów wchodzących do danej grupy;

b - średni współczynnik kierunkowy trendu regionów w grupie.

W tabelach 4-9 wyróżniono pogrubieniem regiony najbardziej typowe w każdej grupie, czyli położone najbliżej jej środka.

Klasę pierwszą nie tylko cechuje najwyższa wartość wskaźnika W (46), ale odnotowano w niej także zdecydowanie najwyższe przeciętne wartości parametru a dla KIS i KIS 2. Zdecydowanie jest to klasa wyspecjalizowanych usług opartych na wiedzy. Ponadto odnotowano raczej słaby przyrost KIS, a dla KIS 2 praktycznie stabilizację. Natomiast dla HIT i HIT 2 oba wskaźniki dynamiki są ujemne. Do klasy tej zaliczono wszystkie regiony duńskie, większość fińskich, belgijskich i szwedzkich oraz połowę holenderskich i co czwarty brytyjski (tab. 3 i 4 oraz ryc. 2).

Tab. 4. Wyniki klasyfikacji - regiony w klasie pierwszej

\begin{tabular}{|l|l|}
\hline \multicolumn{1}{|c|}{ Kraj (\% regionów) } & \multicolumn{1}{c|}{ Regiony } \\
\hline Dania (100) & Hovedstaden, Sjælland, Syddanmark, Midtjylland, Nordjylland \\
\hline Finlandia (80) & Itä-Suomi, Etelä-Suomi, Länsi-Suomi, Åland \\
\hline Belgia (73) & $\begin{array}{l}\text { Région de Bruxelles-Capitale, Prov. Vlaams Brabant, Prov. West- } \\
\text {-Vlaanderen, Prov. Brabant Wallon, Prov. Hainaut, Prov. Liège, Prov. } \\
\text { Luxembourg, Prov. Namur }\end{array}$ \\
\hline Szwecja (63) & $\begin{array}{l}\text { Småland med öarna, Sydsverige, Norra Mellansverige, Mellersta Norrland, } \\
\text { Övre Norrland }\end{array}$ \\
\hline Holandia (50) & Groningen, Gelderland, Flevoland, Utrecht, Noord-Holland, Zuid-Holland \\
\hline Francja (27) & $\begin{array}{l}\text { Île de France, Picardie, Pays de la Loire, Midi-Pyrénées, Rhône-Alpes, } \\
\text { Provence-Alpes- Côte d'Azur }\end{array}$ \\
\hline Wielka Brytania (27) & $\begin{array}{l}\text { Merseyside, North Yorkshire, West Yorkshire, East Anglia, Inner London, } \\
\text { Outer London, Surrey, East and West Sussex, Dorset and Somerset, West } \\
\text { Wales and The Valleys, North Eastern Scotland }\end{array}$ \\
\hline Niemcy (3) & Hamburg \\
\hline
\end{tabular}

Źródło: opracowanie własne

Do klasy drugiej (rozwinięty, wyspecjalizowany i nowoczesny przemysł, wartość współczynnika W na poziomie 44 oraz najwyższa wartość parametru a dla HIT i HIT 2 i jednocześnie dynamika na poziomie ujemnym, co może wskazywać na „hamowanie” tych sektorów w regionach drugiego skupienia) zaliczono Maltę, połowę regionów brytyjskich oraz niemal co piąty region z Niemiec, Finlandii, Belgii, Francji i Holandii (tab. 5). 
Tab. 5. Wyniki klasyfikacji - regiony w klasie drugiej

\begin{tabular}{|l|l|}
\hline \multicolumn{1}{|c|}{ Kraj (\% regionów) } & \multicolumn{1}{|c|}{ Regiony } \\
\hline Malta (100) & Malta \\
\hline Wielka Brytania (54) & $\begin{array}{l}\text { Tees Valey and Durham, Northumberland, Tyne and Wear, Cheshire, } \\
\text { Greater Manchester, Lancashire, Herefordshire, Worchestershire and Warks, } \\
\text { West Midlands, Bedfordshire, Hertfordshire, Essex, Bershire, Bucks and } \\
\text { Oxfordshire, Hampshire and Isle of Wight, Kent, Gloucestershire, Wiltshire } \\
\text { and Bristol, Devon, East Wales, Eastern Scotland, South Western Scotland }\end{array}$ \\
\hline Irlandia (50) & Southern and Eastern \\
\hline Szwecja (38) & Stockholm, Östra Mellansverige, Västsverige \\
\hline Niemcy (23) & $\begin{array}{l}\text { Stuutgart, Tübingen, Mittelfranken, Unterfranken, Schwaben, Darmstadt, } \\
\text { Kassel, Koblenz, Rheinhesses-Pfalz }\end{array}$ \\
\hline Finlandia (20) & Pohjois-Suomi \\
\hline Belgia (18) & Prov. Antwerpen, Prov. Limburg \\
\hline Francja (18) & Haute-Normandie, Bourgogne, Franche-Comté, Bretagne \\
\hline Holandia (17) & Zeeland, Limburg \\
\hline Rumunia (13) & Centru \\
\hline Hiszpania (12) & Communidad Foral de Navarra, Comunidad de Madrit \\
\hline Austria (11) & Wien \\
\hline
\end{tabular}

Źródło: opracowanie własne

Klasę trzecią (tab. 6) cechuje wartość współczynnika W równa 39 oraz najwyższe w relacji do pozostałych klas średnie współczynniki kierunkowe trendu regionów dla KIS i KIS 2 - oznacza to relatywnie wysoką dynamikę wyspecjalizowanych usług. Klasa ta obejmuje dużą reprezentację regionów niemieckich (14), a także włoskich (9), brytyjskich (7), francuskich (5), hiszpańskich oraz holenderskich (po 4) - por. tab. 6.

Tab. 6. Wyniki klasyfikacji - regiony w klasie trzeciej

\begin{tabular}{|l|l|}
\hline \multicolumn{1}{|c|}{ Kraj (\% regionów) } & \multicolumn{1}{c|}{ Regiony } \\
\hline Irlandia (50) & Border, Midlands and Western \\
\hline Słowenia (50) & Zahodna Slovenija \\
\hline Włochy (38) & $\begin{array}{l}\text { Piemonte, Valle d'Aosta/Vallee d'Aoste, Liguria, Lombardia, Trento, Friuli- } \\
\text { Venezia Giulia, Lazio, Basilicata }\end{array}$ \\
\hline Niemcy (36) & $\begin{array}{l}\text { Oberbayern, Berlin, Bremen, Gießen, Hannover, Weser-Ems, Düsseldorf, } \\
\text { Köln, Münster, Detmold, Arnsberg, Dresden, Leipzig, Schleswig-Holstein }\end{array}$ \\
\hline Niderlandy (33) & Friesland, Drenthe, Overijssel, Noord-Brabant \\
\hline Rumunia (25) & Sud-Muntenia, Bucuresti-Ilfov \\
\hline Hiszpania (24) & Cantabria, País Vasco, Aragón, Cataluña \\
\hline Francja (23) & Centre, Basse-Normandie, Nord-Pas-de-Clais, Alsace, Aquitaine \\
\hline United Kingdom (20) & $\begin{array}{l}\text { Cumbria, Eats Yorkshire and Northern Lincolnshire, South Yorkshire, } \\
\text { Shropshire and Staffordshire, Cornwall and Isles of Scilly, Highlands and } \\
\text { Islands, Northern Ireland }\end{array}$ \\
\hline Wegry (14) & Közép-Magyarország \\
\hline Portugalia (14) & Lizboa \\
\hline Czechy (13) & Praha \\
\hline Polska (13) & Opolskie, Pomorskie \\
\hline Austria (11) & Niederösterreich \\
\hline
\end{tabular}

Źródło: opracowanie własne 
W klasie czwartej (tab. 7 i ryc. 2), o współczynniku W=36, charakterystyczne są najwyższe w porównaniu do innych grup średnie współczynniki kierunkowe trendu regionów dla HIT i HIT 2 - co wskazuje na dynamiczny rozwój wyspecjalizowanego przemysłu. Najliczniej reprezentowane w tej klasie są regiony Niemiec (12), Czech (6), Węgier (4), Polski i Włoch (po 3).

Tab. 7. Wyniki klasyfikacji - regiony w klasie czwartej

\begin{tabular}{|l|l|}
\hline Kraj (\% regionów) & Regiony \\
\hline Czechy (75) & $\begin{array}{l}\text { Stredni Cechy, Jihovýchod, Severozápad, Severovýchod, Jihovýchod, } \\
\text { Stredni Morava }\end{array}$ \\
\hline Węgry (57) & Közép-Dunántúl, Nyugat-Dunántúl, Dél-Dunántúl, Észak-Magyarország \\
\hline Słowenia (50) & Vzhodna Slovenija \\
\hline Słowacja (50) & Bratislavský kraj, Západné Slovensko \\
\hline Niemcy (30) & $\begin{array}{l}\text { Karlsruhe, Freiburg, Niederbayern, Oberpfalz, Oberfranken, Brandenburg- } \\
\text { Südwest, Braunschweig, Lüneburg, Saarland, Chemnitz, Sachsen-Anhalt, } \\
\text { Thüringen }\end{array}$ \\
\hline Austria (22) & Steiermark, Oberösterreich \\
\hline Włochy (19) & Veneto, Emilia-Romagna, Marche, Molise \\
\hline Polska (19) & Śląskie, Zachodniopomorskie, Dolnośląskie \\
\hline Rumunia (13) & Vest \\
\hline Belgia (9) & Prov. Oost-Vlaanderen \\
\hline Francja (5) & Lorraine \\
\hline
\end{tabular}

Źródło: opracowanie własne

Najsłabszym przyrostem KIS $(b=0,153)$ oraz spadkiem dla KIS 2 odznacza się klasa piąta (tab. 8), w której wartość współczynnika W wynosiła 26. Było to, ze względu na wartości, drugie miejsce, ale licząc od najmniejszych w uszeregowaniu. Podobnie jest z wartościami parametru a dla każdej z analizowanych cech.

Tab. 8. Wyniki klasyfikacji - regiony w klasie piątej

\begin{tabular}{|l|l|}
\hline \multicolumn{1}{|c|}{ Kraj (\% regionów) } & \multicolumn{1}{c|}{ Regiony } \\
\hline Bułgaria (100) & $\begin{array}{l}\text { Severozapaden, Severen tsentralen, Severoiztochen, Yugoiztochen, } \\
\text { Yugozapaden, Yuzhen tsentralen }\end{array}$ \\
\hline Estonia (100) & Eesti \\
\hline Litwa (100) & Lietuva \\
\hline Łotwa (100) & Latvija \\
\hline Rumunia (50) & Nord-Vest, Nord-Est, Sud-Est, Sud-Vest Oltenia \\
\hline Słowacja (50) & Stredné Slovensko, Východné Slovensko \\
\hline Austria (44) & Kärnten, Salzburg, Tirol, Vorarlberg \\
\hline Polska (38) & $\begin{array}{l}\text { Mazowieckie, Małopolskie, Świętokrzyskie, Lubuskie, Kujawsko- } \\
\text { pomorskie, Warmińsko-mazurskie }\end{array}$ \\
\hline Grecja (31) & Kentriki Makedonia, Thraki, Peloponnisos, Attiki, Voreio Aigaio \\
\hline Francja (23) & $\begin{array}{l}\text { Champagne-Ardenne, Poitou-Charentes, Limousin, Languedoc-Roussillon, } \\
\text { Corse }\end{array}$ \\
\hline Węgry (14) & Észak-Alföld \\
\hline
\end{tabular}




\begin{tabular}{|l|l|}
\hline Hiszpania (12) & Castilla y León, Communidad Valenciana \\
\hline Włochy (10) & Campania, Calabria \\
\hline Niemcy (3) & Trier \\
\hline
\end{tabular}

Źródło: opracowanie własne

W klasie szóstej wartość współczynnika W jest niemal dwukrotnie niższa niż w klasie pierwszej, zaś wartości średniego wyrazu wolnego trendu (a) dla cech ilustrujących nowoczesny przemysł i usługi regionów wchodzących do tej grupy są najniższe. W klasie tej sytuuje się większość regionów Portugalii, Grecji, Hiszpanii, co trzeci region we Włoszech i Polsce oraz Cypr i Luksemburg (tab. 9).

Tab. 9. Wyniki klasyfikacji - regiony w klasie szóstej

\begin{tabular}{|l|l|}
\hline \multicolumn{1}{|c|}{ Kraj (\% regionów) } & \multicolumn{1}{|c|}{ Regiony } \\
\hline Cypr (100) & Kypros \\
\hline Luksemburg (100) & Luxembourg \\
\hline Portugalia (86) & $\begin{array}{l}\text { Norte, Algarve, Centro, Alentejo, Região Autónoma dos Açores, Região } \\
\text { Autónoma da Madeira }\end{array}$ \\
\hline Grecja (69) & $\begin{array}{l}\text { Anatoliki Makedonia, Dytiki Makedonia, Thessalia, Ipeiros, Ionia Nisia, } \\
\text { Dykiti Ellada, Sterea Ellada, Notio Aigaio, Kriti }\end{array}$ \\
\hline Hiszpania (53) & $\begin{array}{l}\text { Galicia, Principado de Asturias. La Rioja, Castilla-la Mancha, } \\
\text { Extremadura, Illes Balears, Andalucia, Region de Murcia, Canarias }\end{array}$ \\
\hline Włochy (33) & $\begin{array}{l}\text { Provincia Autonoma Bolzano-Bozen, Toscana, Umbria, Abruzzo, Puglia, } \\
\text { Sicilia, Sardegna }\end{array}$ \\
\hline Polska (31) & Łódzkie, Lubelskie, Podkarpackie, Podlaskie, Wielkopolskie \\
\hline Węgry (14) & Dél-Alföld \\
\hline Czechy (13) & Moravskoslezsko \\
\hline Austria (11) & Burgenland \\
\hline Niemcy (5) & Brandenburg-Nordost, Mecklenburg-Vorpommern \\
\hline Francja (5) & Auvergne \\
\hline
\end{tabular}

Źródło: opracowanie własne

Graficzną prezentację rozmieszczenia klas regionów UE, wydzielonych ze względu na dynamikę zatrudnienia w nowoczesnym przemyśle i usługach opartych na wiedzy, przedstawiono na rycinie 2 .

Na rycinie 3 - ilustrującej przeciętne trendy analizowanych cech w wyróżnionych grupach regionów widać, że kluczowe znaczenie dla różnicowania grup miał jednak poziom charakterystyki rynku pracy. W przypadku udziału pracujących w nowoczesnym przemyśle zaznaczyły się dwa wyraźne trendy, które doprowadziły do zmiany pozycji grupy w hierarchii na końcu badanego okresu. W regionach przyporządkowanych do klasy drugiej zanotowano wyraźny spadek udziału zatrudnienia, natomiast w grupie czwartej zdecydowany przyrost. 


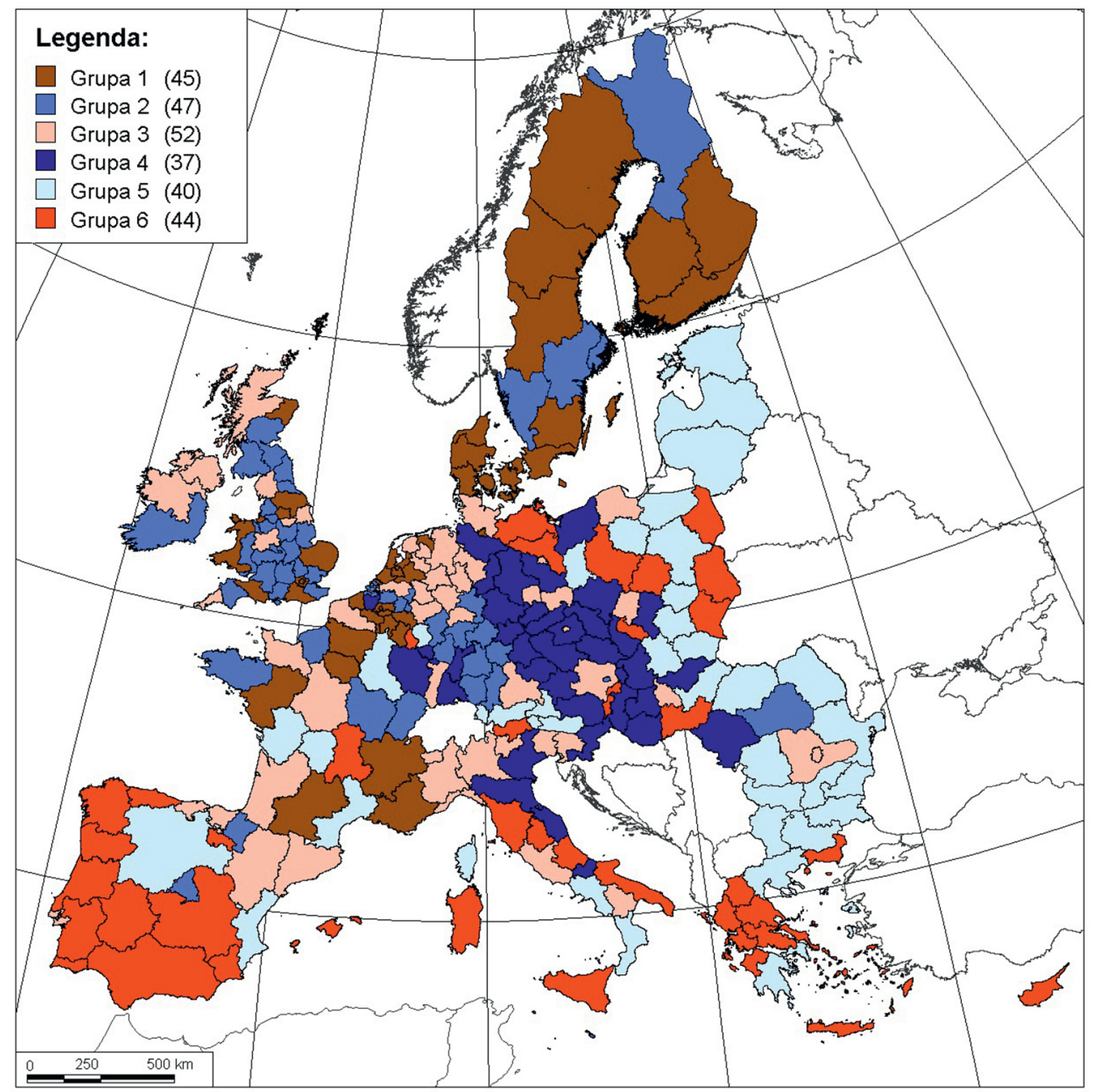

Ryc. 2. Wyniki klasyfikacji regionów UE pod względem dynamiki zatrudnienia w nowoczesnym przemyśle i usługach opartych na wiedzy

Źródło: opracowanie własne

W odniesieniu do udziału zatrudnionych w nowoczesnych usługach znamienne jest, że największy przyrost zanotowano w najsłabszej grupie regionów. Podobny co do tempa trend (mniej więcej równoległe trendy liniowe) zanotowano dla regionów grupy trzeciej. Prawdopodobnie badany okres jest zbyt krótki, aby ujawniły się pożądane przekształcenia w strukturze zatrudnienia, a i sama struktura charakteryzuje się pewną naturalną inercją. 

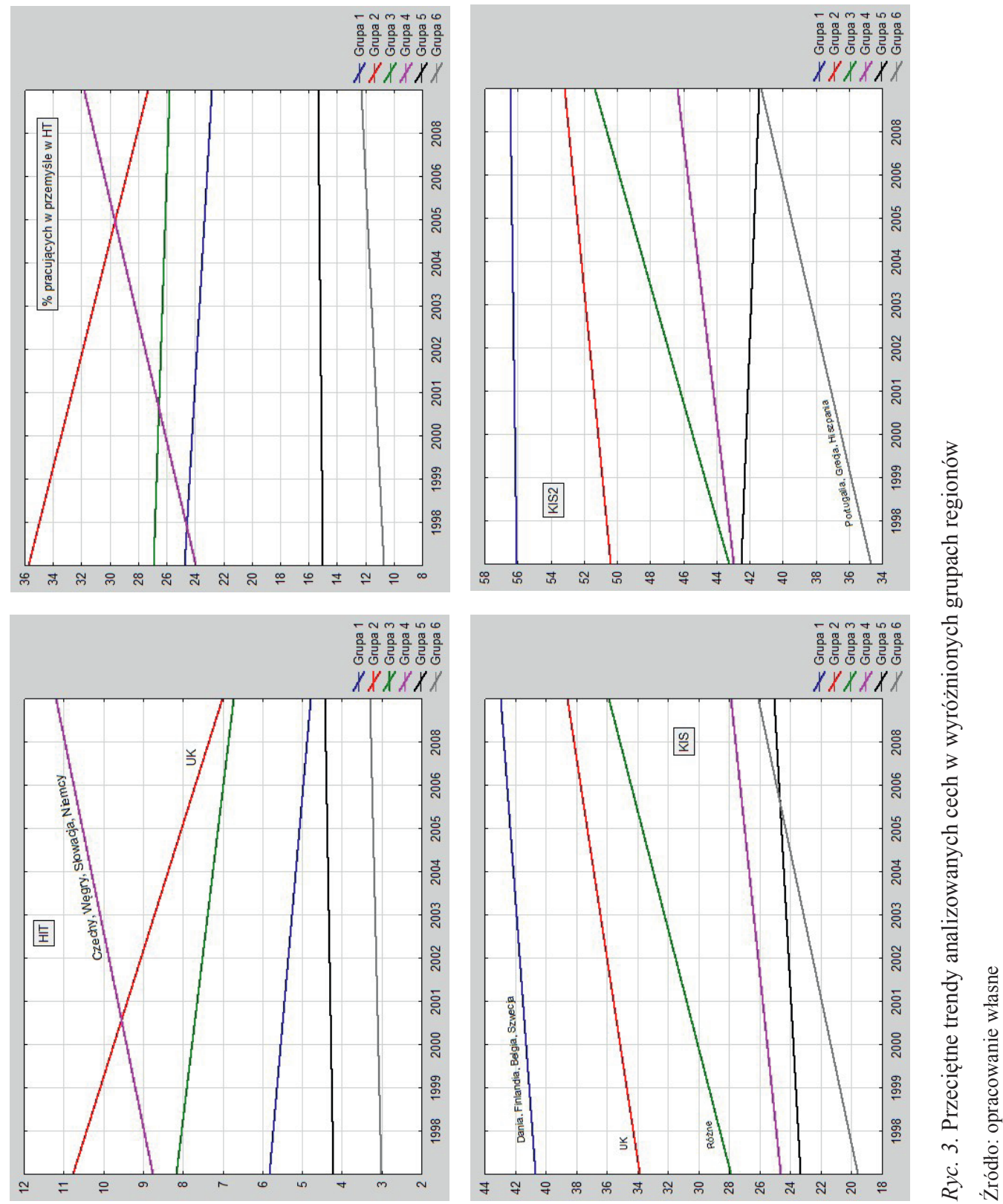
Podsumowanie

Intensywne zmiany strukturalne są charakterystyczne szczególnie dla okresu rozwoju gospodarczego o wysokim tempie postępu technicznego i organizacyjnego, w którym dokonują się głębokie modernizacje i przeobrażenia systemowe, silne zmiany w handlu światowym, ale towarzyszą też okresowi stagnacji czy kryzysu. Duża intensywność zmian strukturalnych - jeśli zachodzi w kierunku dodatniej dynamiki - stanowi zjawisko korzystne. Jest bowiem zwykle wyrazem dążenia przedsiębiorstw do efektywniejszego wykorzystania zasobów i potencjału gospodarki kraju i regionu. Natomiast w czasie hamowania gospodarki i w okresie stagnacji obserwowane są zmiany w kierunku zmniejszania się znaczenia gospodarczego niektórych sektorów i branż, co znajduje odzwierciedlenie w spadku ich udziałów ocenianych np. z perspektywy liczby pracujących czy PKB.

Na rycinie 4 przedstawiono wykres ramkowy ilustrujący przeciętny poziom stopy bezrobocia w 2012 roku, czyli cztery lata po końcu okresu, w którym analizowaliśmy zmiany struktury zatrudnienia w kierunku wzrostu udziału zatrudnienia w nowoczesnym przemyśle i usługach. Zdecydowanie najwyższe bezrobocie było w regionach należących do grupy, gdzie udział zatrudnienia w tych sekcjach był najmniejszy, a odnotowane pozytywne zmiany okazały się niewystarczające dla pozytywnego oddziaływania na zmniejszenie bezrobocia.

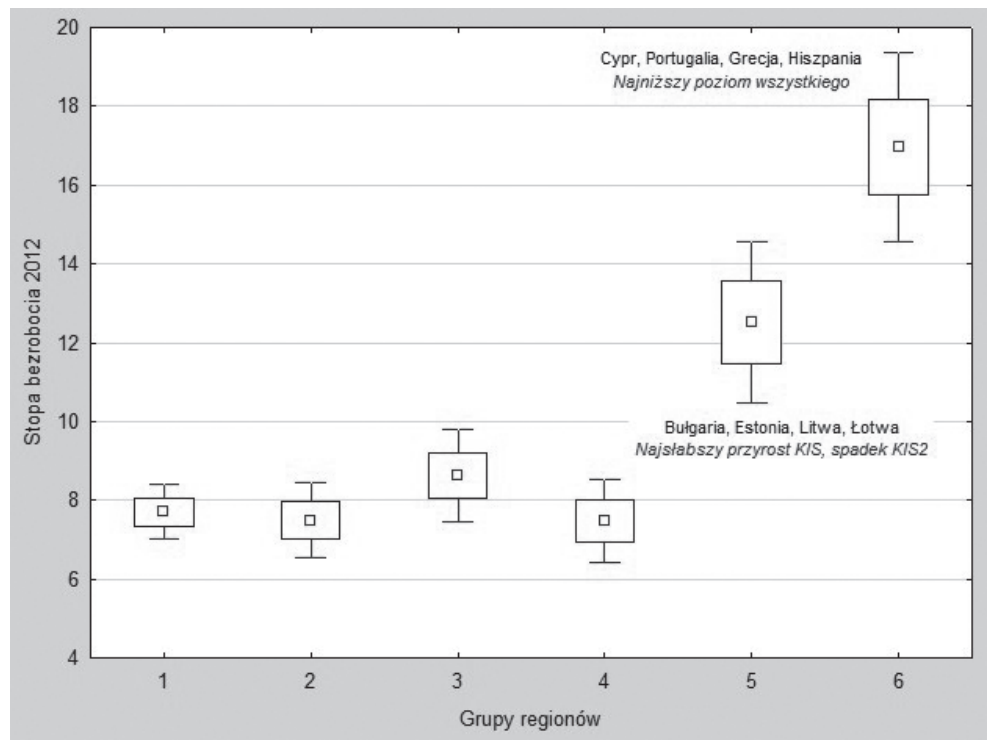

Ryc. 4. Rysunek ramkowy (średnia/błąd średniej/95\% przedział ufności) dla stopy bezrobocia w 2011 roku w wyróżnionych grupach regionów UE

Źródło: opracowanie własne

Na drugim miejscu pod względem średniej stopy bezrobocia znalazła się grupa regionów o najsłabszym przyroście udziału zatrudnionych w nowoczesnych usługach w liczbie 
zatrudnionych ogółem, przy wręcz spadku udziału pracujących w usługach opartych na wiedzy w liczbie zatrudnionych w usługach ogółem. Pozostałe grupy regionów wykazywały średnią stopę bezrobocia na poziomie jednocyfrowym.

Otrzymane wyniki klasyfikacji regionów europejskich zdają się pokazywać, że typologia nie wskazuje właściwie na określone właściwości grup regionów związane z przynależnością do poszczególnych państw. Oznaczać to może, że w zakresie rynku pracy pewne tendencje są porównywalne już w wielu krajach UE. Natomiast widoczna jest pewna specyfika terytorialna z uwagi na zatrudnienie i dynamikę w wyspecjalizowanych usługach opartych na wiedzy. Bowiem do klasy tej zaliczono wszystkie regiony duńskie, większość fińskich, belgijskich i szwedzkich oraz połowę holenderskich i co czwarty brytyjski - a więc w grupie tej są regiony sześciu tylko państw, i to w liczbie wyraźnie znaczącej (połowa lub ponad połowa regionów w tych krajach).

\section{Literatura \\ References}

Chenery, H., Robinson, S., Syrquin, M. (1986). Industrialization and growth. A Comparative Study. Published for the World Bank, Oxfrod University Press.

Handbook on Constructing Composite Indicators. Methodology and User Guide (2008). OECD, Paris. Klasik, A. (red.). (2011). Kreatywne przemysły - kreatywne aglomeracje. Biuletyn KPZK PAN, 246.

Lux, G. (2010). Location differences of services and industry: A Central European dichotomy, Prace Komisji Geografii Przemystu Polskiego Towarzystwa Geograficznego, 16, 29-37

Machlup F. (1991). Economic Semantics. New Brunswick, New Jersey: Transaction Publishers.

Markowska, M. (2012). Dynamiczna taksonomia innowacyjności regionów. Wrocław: Wydawnictwo Uniwersytetu Ekonomicznego we Wrocławiu, Monografie i Opracowania, 221.

Memedovic, O., Iapadre, L. (2010). Structural Change in the World Economy: Main Features and Trends. Research and Statistics Branch Working Paper, 24/2009. Vienna: United Nations Industrial Development Organization.

Quesnay, F. (1758). Tableau Économique'. W: H. Hagemann, M. Landesmann, R. Scazzieri (red.). The Economics of Structural Change, Vol. III, International Library of Critical Writings. Cheltenham: Edward Elgar, 29-41.

Regions in the European Union. Nomenclature of territorial units for statistics NUTS 2006/EU-27 (2007). Methodologies and Working Papers, European Commission, Luxemburg.

Ricardo, D. (1817). The Principles of Political Economy and Taxation. W: Hagemann H., Landesmann M., Scazzieri R. (red.). Vol. I, Critical Writings. 2003, Aldershot: Edward Elgar.

Rodionova, I., Kokuytseva, T. (2010). Structural changes of world industry in postindustrial society and structural shifts in the world high-tech production allocation. Prace Komisji Geografii Przemystu Polskiego Towarzystwa Geograficznego, 16, 38-50.

Smith, A. (1976). An Inquiry into the Nature and Causes of the Wealth of Nations. R.H.Campbell, A.S. Skinner, W.B. Todd (red.). Oxford: Clarendon Press.

Steuart, J. (1767). An Inquiry into the Principles of the Political Economy. Reprint (1966). A.S. Skinner (red.) Edinburgh and London: Oliver and Boyd.

Syrquin, M. (2007). Kuznets and Pasinetti on the study of structural transformation: Never the Twain shall meet? ICER, Working Paper, 46.

Turgot, A.R.J. (1766). Reflections on the Formation and the Distribution of Wealth., W: Meek R. L. (ed.). Turgot on Progress, Sociology and Economics, 119-134, Cambridge: Cambridge University Press. 
Ward, J.H. (1963). Hierarchical grouping to optimize an objective function. Journal of the American Statistical Association, 58(301), 236-244.

Zioło, Z. (2012). Rola przemysłu i usług w kształtowaniu gospodarki opartej na wiedzy, Prace Komisji Geografii Przemystu Polskiego Towarzystwa Geograficznego, 20, 11-30.

Zioło, Z. (2010). Uwarunkowania kształtowania się procesów transformacji przemysłu i usług. Prace Komisji Geografii Przemystu Polskiego Towarzystwa Geograficznego, 15, 45-60.

Małgorzata Markowska, dr hab. prof. UE, Uniwersytet Ekonomiczny we Wrocławiu, Wydział Ekonomii, Zarządzania i Turystyki w Jeleniej Górze. Jest profesorem Uniwersytetu Ekonomicznego we Wrocławiu w Katedrze Gospodarki Regionalnej, członkiem Sekcji Klasyfikacji i Analizy Danych oraz Regional Studies Association - sekcja polska. Realizuje badania naukowe dotyczące pomiaru, oceny, zróżnicowania, dynamiki zmian takich zjawisk, jak m.in.: rozwój, konkurencyjność, gospodarka oparta na wiedzy, inteligentne specjalizacje, konwergencja i innowacyjność w europejskiej przestrzeni na szczeblu regionalnym z wykorzystaniem metod ekonometrycznych. Jest autorką lub współautorką ponad 100 artykułów naukowych, monografii (Dynamiczna taksonomia innowacyjności regionów) oraz 25 rozdziałów w monografiach. Współpracowała w realizacji 10 grantów finansowanych z funduszy ministerialnych i NCN oraz kilku projektów unijnych. Wygłosiła 120 referatów na krajowych i zagranicznych konferencjach naukowych. Brała udział w pracach badawczych na rzecz instytucji rządowych, samorządów i praktyki gospodarczej.

Malgorzata Markowska is an associate professor at the Regional Economics Chair of Wrocław University of Economics. She is a member of Polish Classification Society and Polish section of Regional Studies Association. Her research deals with econometric measurement, evaluation, variability and dynamics of development of fields such as competitiveness, Knowledge Based Economics, smart specializations, convergence and innovativeness in European regional space. As the author or co-author she published more than 100 scientific papers and 25 chapters in books, and recently her own dissertation "Dynamic Taxonomy of Regions' Innovativeness". She took part in 10 scientific projects financed by Polish National Centre of Science and European Union, and in projects for governmental, local administration and business units.

\section{Adres/adress:}

Uniwersytet Ekonomiczny we Wrocławiu

Wydział Ekonomii, Zarządzania i Turystyki w Jeleniej Górze

ul. Nowowiejska 3, 58-500 Jelenia Góra, Polska

e-mail: malgorzata.markowska@ue.wroc.pl

Danuta Strahl, prof. dr hab., Uniwersytet Ekonomiczny we Wrocławiu, Wydział Ekonomii, Zarządzania i Turystyki w Jeleniej Górze. Jest profesorem nauk ekonomicznych w Katedrze Gospodarki Regionalnej Uniwersytetu Ekonomicznego we Wrocławiu. Od 1992 roku jest członkiem Komitetu Statystyki i Ekonometrii Polskiej Akademii Nauk oraz od 2008 roku członkiem Komitetu Nauk Ekonomicznych Polskiej Akademii Nauk. Jej zainteresowania naukowe skupiają się na wykorzystaniu metod wielowymiarowej analizy statystycznej w badaniach regionalnych, a w szczególności na rozwoju regionalnym, gospodarce opartej na wiedzy i rozwoju inteligentnym europejskiej przestrzeni regionalnej. Jest autorką lub współautorką ponad 150 artykułów, redaktorem i autorem lub współautorem 10 monografii. Wygłosiła ponad 100 referatów na konferencjach naukowych.

Danuta Strahl is the professor of economic sciences at the Department of Regional Economy of Wrocław University of Economics. Since 1992 she has been a member of the Committee of Statistics and Econometrics of Polish Academy of Sciences and since 2008 a member of the C ommittee of Economic Sciences of Polish Academy of Sciences. Her scientific interests focus on the application of multivariate statistical analysis methods in regional research, and in particular on regional development, knowledge-based economy and smart development of the European regional space. She is the 
author or co-author of over 150 articles as well as the editor and author or co-author of 10 monographs. She has delivered over 100 papers at scientific conferences.

\section{Adres/adress:}

Uniwersytet Ekonomiczny we Wrocławiu

Wydział Ekonomii, Zarządzania i Turystyki w Jeleniej Górze

ul. Nowowiejska 3, 58-500 Jelenia Góra, Polska

e-mail: danuta.strahl@ue.wroc.pl

Andrzej Sokołowski, dr hab. prof. UEK, Uniwersytet Ekonomiczny w Krakowie, Wydział Zarządzania. Andrzej Sokołowski jest profesorem Uniwersytetu Ekonomicznego w Krakowie, kierownikiem Zakładu Statystyki. Jego zainteresowania naukowe obejmują szeroki zakres zastosowań statystyki, w naukach ekonomicznych, medycynie, sporcie i kulturze fizycznej, polityce i muzyce. W zakresie teoretycznych zagadnień statystycznych jego głównym polem zainteresowań jest statystyka matematyczna, metody analiz wielowymiarowych oraz statystyka medyczna. Jest autorem ponad 60 rozdziałów w monografiach lub książek, 143 artykułów naukowych oraz 128 wystąpień na konferencjach naukowych. Przez trzy kadencje był Przewodniczącym Sekcji Klasyfikacji i Analizy Danych Polskiego Towarzystwa Statystycznego, a od ponad 10 lat jest członkiem Rady International Federation of Classification Societies.

Andrzej Sokołowski is an associate professor and Head of Department of Statistics at Cracow University of Economics. His scientific activity is concentrated on application of statistical methods in fields such as economics and management, medicine, sports, politics and music. In theoretical statistics he is interested in mathematical statistics, multivariate analysis and medical statistics. He is the author of more than 60 chapters in books and monographs, 143 scientific papers and 128 contribution at conferences. For three terms he was President of Polish Classification Society and for more than ten years he has beena member of International Federation of Classification Societies Council.

\section{Adres/adress:}

Uniwersytet Ekonomiczny w Krakowie

Wydział Zarządzania

ul. Rakowicka 27, 31-510 Kraków, Polska

e-mail: andrzej.sokolowski@uek.krakow.pl 